Research Paper

\title{
Silicon alleviates ammonium toxicity in cauliflower and in broccoli
}

\author{
Rafael Ferreira Barreto*, Aparecido Alecio Schiavon Júnior, Marcos Aurélio Maggio, \\ Renato de Mello Prado
}

São Paulo State University (UNESP), School of Agricultural and Veterinarian Sciences, Jaboticabal, Brazil

\section{A R T I C L E I N F O}

\section{Keywords:}

Abiotic stress

Brassica oleracea

Beneficial element

$\mathrm{NO}_{3}{ }^{-} / \mathrm{NH}_{4}{ }^{+}$ratios

Nutrient solution

\begin{abstract}
A B S T R A C T
Plant growth may be higher with a nitrate $\left(\mathrm{NO}_{3}{ }^{-}\right)$and ammonium $\left(\mathrm{NH}_{4}{ }^{+}\right)$ratio (N-A ratio), in relation to a particular form of $\mathrm{N}$. However, the $\mathrm{NH}_{4}{ }^{+}$can be toxic. In order to alleviate $\mathrm{NH}_{4}{ }^{+}$toxicity in plants, silicon (Si) can be used. To evaluate the effect of N-A ratios and Si in cauliflower and broccoli, the plants were grown in hydroponic system, using coarse sand substrate. Randomized block design was used, with four replications, in a $3 \times 2$ factorial scheme, corresponding to total $\mathrm{N}$ concentration of $15 \mathrm{mmol} \mathrm{L}^{-1}$, with $\mathrm{N}$-A ratios of 100/0,50/50

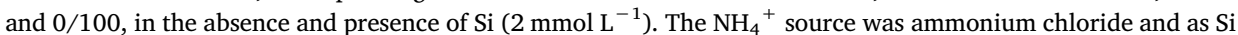
source, stabilized sodium and potassium silicate. The results suggest that in cauliflower, the alleviation of $\mathrm{NH}_{4}^{+}$ toxicity using Si can be noticed through the increase of the physical integrity of the membranes and in broccoli, the alleviation of $\mathrm{NH}_{4}{ }^{+}$toxicity is associated most with the water use efficiency. Si alleviates $\mathrm{NH}_{4}{ }^{+}$toxicity in cauliflower when the total $\mathrm{N}$ concentration is $15 \mathrm{mmol} \mathrm{L}^{-1}$ and $50 \%$ is supplied in the form of $\mathrm{NH}_{4}{ }^{+}$. In broccoli, $\mathrm{Si}$ improves the effect of $\mathrm{NO}_{3}{ }^{-}$and alleviates $\mathrm{NH}_{4}{ }^{+}$toxicity.
\end{abstract}

\section{Introduction}

Ammonium $\left(\mathrm{NH}_{4}{ }^{+}\right)$is one of the main forms of nitrogen $(\mathrm{N})$ which is responsible for the biosynthesis of amino acids and provides less energetic waste for plants, since it is in a readily assimilable form. However, $\mathrm{NH}_{4}{ }^{+}$accumulation in plant cell leads to oxidative stress, due to the increase in the production of reactive oxygen species, causing toxicity (Bittsánszky et al., 2015). Another consequence of $\mathrm{NH}_{4}{ }^{+}$toxicity is to decrease the accumulation of cations such as potassium $\left(\mathrm{K}^{+}\right)$, calcium $\left(\mathrm{Ca}^{2+}\right)$ and magnesium $\left(\mathrm{Mg}^{2+}\right)$ (Nasraoui-Hajaji and Gouia, 2014).

Since $\mathrm{K}^{+}$and $\mathrm{NH}_{4}{ }^{+}$are very similar in relation to valence and ionic radius, they may not be distinguished by membrane bound-carrier. Thus, at high concentrations of $\mathrm{NH}_{4}{ }^{+}, \mathrm{K}^{+}$uptake decreases (Ten Hoopen et al., 2010). In addition, in $\mathrm{NO}_{3}{ }^{-}$fed plants, the external $\mathrm{pH}$ usually increases considerably with time, and with $\mathrm{NH}_{4}{ }^{+}$supply, the external pH decreases (Marschner 2012). The consequence of acidification is the lower availability of cations, such as $\mathrm{K}^{+}, \mathrm{Ca}^{2+}$ and $\mathrm{Mg}^{2+}$ (Ahmad et al., 2006).

In this context, plant growth may be higher with a N-A ratio, in relation to a particular form of N. For example, in broccoli plants fed with low $\mathrm{N}$ concentration $\left(3.5 \mathrm{mmol} \mathrm{L}^{-1}\right)$, the highest dry weight was obtained with a N-A ratio of 50/50 (Zaghdoud et al., 2016a). At high N concentration $\left(18 \mathrm{mmol} \mathrm{L}^{-1}\right)$, the highest dry weight of broccoli was obtained in the proportion of 25/75 (Liu and Shelp, 1993). However, in cauliflower plants fed with low $\mathrm{N}$ concentration $\left(3.5 \mathrm{mmol} \mathrm{L}^{-1}\right)$, there was no difference in dry weight as a function of the N-A ratios 100/0 and 50/50. In the three studies, symptoms of toxicity in the plants were verified when $\mathrm{N}$ was totally supplied in the form of $\mathrm{NH}_{4}{ }^{+}$.

In order to alleviate $\mathrm{NH}_{4}{ }^{+}$toxicity in plants, and improves the effect of $\mathrm{NO}_{3}{ }^{-}$, Si can be used. For example, in Brassica napus fed with $14 \mathrm{mmol} \mathrm{L}^{-1}$ of $\mathrm{N}$, Si increased leaf area and fresh weight in N-A ratios ranging from 100/0 to 25/75 (Bybordi 2010).

Despite the importance of brassicas, studies on the role of $\mathrm{Si}$ in the mitigation of $\mathrm{NH}_{4}^{+}$toxicity to cauliflower and broccoli are scarce. However, there is a hypothesis that $\mathrm{Si}$ can alleviate $\mathrm{NH}_{4}{ }^{+}$toxicity in cauliflower and broccoli crops. Thus, this study aimed to evaluate the effect of $\mathrm{Si}$ and N-A ratios on cauliflower and broccoli plants, in hydroponic cultivation.

\section{Material and methods}

\subsection{Plant material and growth conditions}

The seeds of cauliflower (Brassica oleracea var. Botrytis) cv Barcelona (production cycle $=110$ days) and broccoli (Brassica oleracea var. Italica) cv BRO 68 (production cycle $=90$ days) were sown in polystyrene trays with 128 cells, containing commercial substrate

\footnotetext{
* Corresponding author at: Via de Acesso Prof. Paulo Donato Castelane, Vila Industrial, Jaboticabal, São Paulo State, Zip code: 14884-900, Brazil.

E-mail addresses: rafael.fb@outlook.com (R. Ferreira Barreto), alecio.schiavon@syngenta.com (A.A. Schiavon Júnior), marcos.maggio@syngenta.com (M.A. Maggio), rmprado@fcav.unesp.br (R. de Mello Prado).
} 


\section{Transplantation and Start of $\mathrm{NO}_{3}-\mathrm{NH}_{4}^{+}$ start of $\mathrm{Si}$ application ratios application}

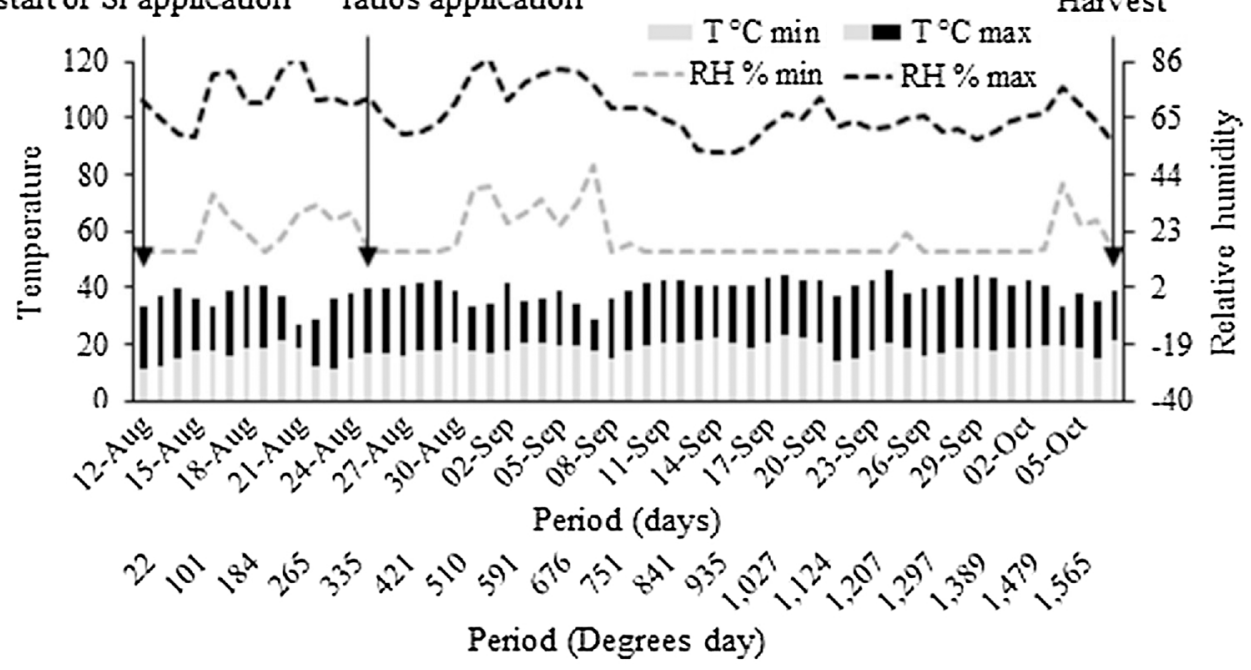

Fig. 1. Temperature and relative humidity at greenhouse during the entire period of experiment.

Table 1

Nutrient solution composition ( $\left.\mathrm{mmol} \mathrm{L}^{-1}\right)$ at a constant $\mathrm{N}$ concentration $\left(15 \mathrm{mmol} \mathrm{L}^{-1}\right)$ and different $\mathrm{N}-\mathrm{A}$ ratios.

\begin{tabular}{|c|c|c|c|c|c|c|}
\hline \multirow[t]{2}{*}{ Nutrient source } & \multicolumn{6}{|c|}{ Nitrate-Ammonium ratios in the nutrient solutions } \\
\hline & $100 / 0$ & $50 / 50$ & $0 / 100$ & $100 / 0$ & $50 / 50$ & $0 / 100$ \\
\hline $\mathrm{KH}_{2} \mathrm{PO}_{4}$ & 0.50 & 0.50 & 0.50 & 0.50 & 0.50 & 0.50 \\
\hline $\mathrm{KNO}_{3}$ & 5.00 & - & - & 5.00 & - & - \\
\hline $\mathrm{Ca}\left(\mathrm{NO}_{3}\right)_{2}$ & 5.00 & 3.75 & - & 5.00 & 3.75 & - \\
\hline $\mathrm{MgSO}_{4}$ & 1.00 & 1.00 & 1.00 & 1.00 & 1.00 & 1.00 \\
\hline $\mathrm{KCl}$ & 0.19 & 5.19 & 5.19 & - & 5.00 & 5.00 \\
\hline $\mathrm{NH}_{4} \mathrm{Cl}$ & - & 7.50 & 15.00 & - & 7.50 & 15.00 \\
\hline $\mathrm{CaCl}_{2}$ & - & 1.25 & 5.00 & - & 1.25 & 5.00 \\
\hline $\begin{array}{l}\text { Stabilized sodium } \\
\text { and potassium } \\
\text { silicate }\end{array}$ & - & - & - & 2.00 & 2.00 & 2.00 \\
\hline
\end{tabular}

Fibramix ${ }^{\oplus}$, composed of coconut fiber $(50 \%)$, carbonized rice husk $(30 \%)$ and ground phenolic foam (20\%).

Ten days after sowing (DAS), the cotyledon leaves had fully expanded. When the cauliflower and broccoli showed four and two expanded leaves (24 DAS), respectively, the seedlings were transplanted into $5 \mathrm{~L}$ polypropylene pots, filled with coarse sand, which had been previously washed. The plants were watered with $10 \%$ of the ionic strength Hoagland nutrient solution (Hoagland and Arnon 1950) until they reach five and three leaves (31 DAS) and with 25\% until they reach seven and four leaves (37 DAS), respectively, for cauliflower and broccoli. The greenhouse temperatures and relative humidity were monitored (Fig. 1). Additionally, the period of the experiment was presented in degrees-day. In order to calculate, base temperature of $0{ }^{\circ} \mathrm{C}$ was used (Grevsen 1998) and evaluated the daily thermal units accumulated throughout the experiment, according to the equation:

$D D=(M t-B t)+((M T-M t) / 2) ;(B t<M t)$

Where:

$$
\begin{aligned}
& \mathrm{DD}={ }^{\circ} \text {-day; } \\
& \mathrm{MT}=\text { daily maximum temperature; } \\
& \mathrm{Mt}=\text { daily minimum temperature; }
\end{aligned}
$$

$\mathrm{Bt}=$ basal temperature

\subsection{Si and $N-A$ ratios treatments}

After the seedling transplanting, Hoagland nutrient solution (Hoagland and Arnon 1950) was applied, to half of cauliflower and broccoli plants, supplemented with $2 \mathrm{mmol} \mathrm{L}^{-1}$ silicon, using stabilized sodium and potassium silicate (114.91 $\mathrm{g} \mathrm{L}^{-1} \mathrm{Si}$ and $18.9 \mathrm{~g} \mathrm{~L}^{-1} \mathrm{~K}_{2} \mathrm{O}$ ).

When the cauliflower and broccoli reached seven and four leaves (37 DAS), respectively, Hoagland nutrient solution (Hoagland and Arnon 1950) was modified, in order to supply $15 \mathrm{mmol} \mathrm{L}^{-1} \mathrm{~N}$ in three $\mathrm{N}-\mathrm{A}$ ratios $(100 / 0,50 / 50$ and $0 / 100)$. The details are shown in Table 1. Final concentration of macronutrients, in $\mathrm{mmol} \mathrm{L}^{-1}$, was N 15; P 0.5 ; K 5.69; Ca 5; $\mathrm{Mg} 1 ; \mathrm{S} 1$. In relation to micronutrients, the only modification recommended by Hoagland and Arnon (1950) was about Fe source, using Fe-EDDHA and twice the recommendation. Modifications with $\mathrm{Si}$ and with $\mathrm{N}-\mathrm{A}$ ratios were balanced varying the concentration of $\mathrm{Cl}$, in order to keep the same concentration of the other nutrients in all treatments. After preparing the solutions, $\mathrm{pH}$ was adjusted $(5.7 \pm 0.2)$. For cauliflower and broccoli, randomized block design was used, in a $2 \times 3$ factorial scheme, with four replications.

Until cauliflower and broccoli reached seven and four leaves, respectively, in each pot, $200 \mathrm{~mL}$ of nutrient solution had been applied daily. Then, the volume applied was of $300 \mathrm{~mL}$. In the base of the pots, holes and polypropylene plates allowed the nutrient solution retention.

\subsection{Total chlorophyll, stomatal conductance, water use efficiency and electrolyte leakage index analysis}

Evaluations of chlorophyll, stomatal conductance, water use efficiency and electrolyte leakage index were carried in the fourth and fully expanded leaf of the plants. Total chlorophyll was determined according to the methodology proposed by Lichtenthaler (1987). Stomatal conductance was measured between 8 and 10 am using a portable photosynthesis system, Li-6400 (LI-COR, EUA). Water use efficiency (WUE) was calculated as net photosynthetic rate $(A)$ per transpiration rate $(E)$ :

$W U E=A / E$ 

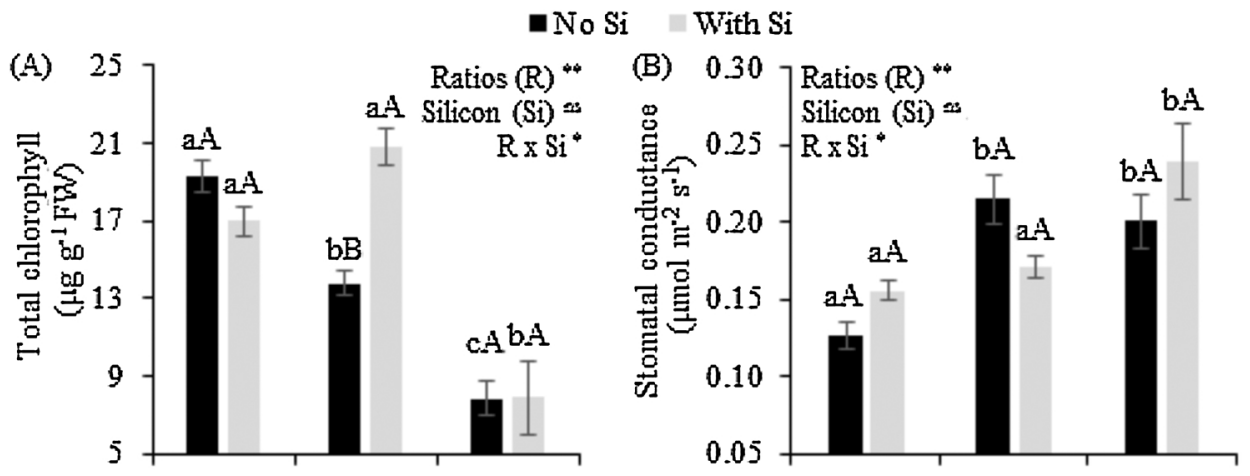

Fig. 2. Effect of $\mathrm{Si}$ and $\mathrm{N}-\mathrm{A}$ ratios on (A) total chlorophyll, (B) stomatal conductance, (C) water use efficiency and (D) electrolyte leakage index of cauliflower shoots. The error bars in the figures represent standard error. Different letters, lowercase between $\mathrm{N}$-A ratios in same $\mathrm{Si}$ concentration, and uppercase between $\mathrm{Si}$ in same $\mathrm{N}-\mathrm{A}$ ratio indicate differences $(\mathrm{P}<0.05$, Tukey test) between treatments.
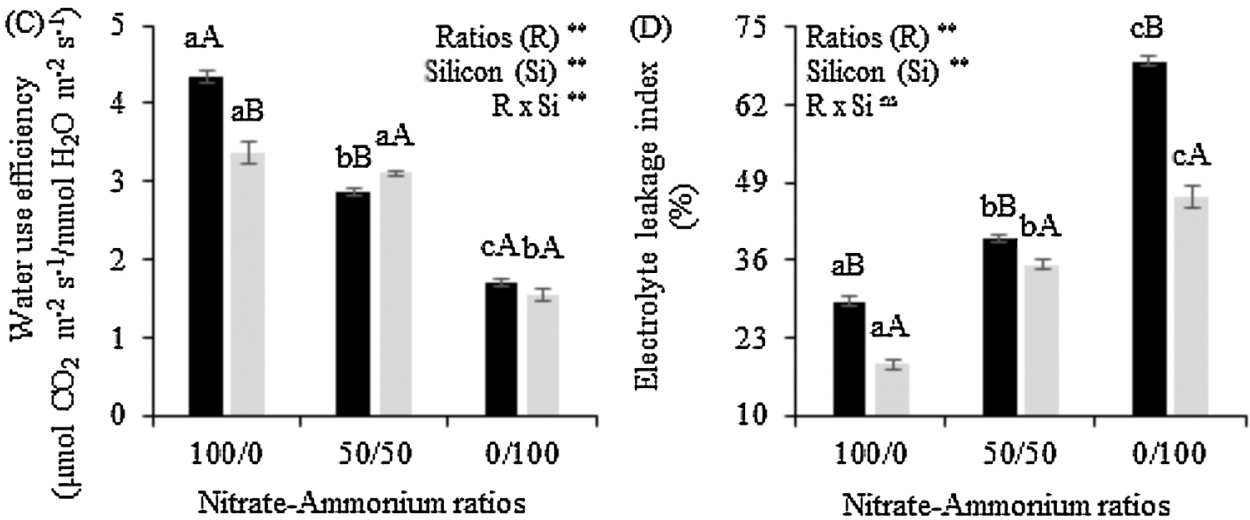

To estimate electrolyte leakage index, the leaves were before rinsed with deionized water. Ten leaf discs (each $6 \mathrm{~mm}$ in diameter) were placed in a glass vial. The vials were then filled with $20 \mathrm{~mL}$ deionized water maintained at the constant temperature of $25^{\circ} \mathrm{C}$. After $2 \mathrm{~h}$, the initial electrical conductivity (EC1) was measured using an electrical conductivity meter. The samples were autoclaved afterwards at $121{ }^{\circ} \mathrm{C}$ for $20 \mathrm{~min}$ to completely kill the tissues and release all electrolytes. Samples were then cooled to $25^{\circ} \mathrm{C}$ and the final electrical conductivity (EC2) was measured. The electrolyte leakage index (ELI) was expressed following the formula proposed by Dionisio-Sese and Tobita, (1998):

$E L I=\frac{E C 1}{E C 2} \times 100$

\subsection{The analysis of $\mathrm{N}, \mathrm{K}, \mathrm{Ca}, \mathrm{Mg}$ and Si contents}

The analyses of $\mathrm{N}, \mathrm{K}, \mathrm{Ca}, \mathrm{Mg}$ and $\mathrm{Si}$ contents were carried out in the shoot of the plants, according to the methodology described by Bataglia et al. (1983) and analysis of Si, according to Korndorfer et al. (2004). Based on the contents (C) of nutrients and Si in shoot, and shoot dry weight, the accumulation (A) of these elements was calculated:

$A=C \times d r y$ weight

\subsection{Plant growth analysis}

Leaf area was measured using a leaf-area meter (L-3100, Li-Cor, USA).

The plants were separated into shoot and roots. The roots were washed with running water. The shoot was washed under running water, mild detergent $(0.1 \%)$, hydrochloric acid solution $(0.3 \%)$ and deionized water. Plant material was dried out in forced air circulation $\left(65 \pm 5{ }^{\circ} \mathrm{C}\right.$ ), until they reached constant mass. After drying, the dry weight of the shoot and root was obtained.

\subsection{Images of roots}

The new and thin roots were selected and photographed in the stereomicroscope Leica M205C ${ }^{\circ}$.

\subsection{Statistic analysis}

The data obtained were subjected to analysis of variance, by $\mathrm{F}$ test, and then subjected to Tukey test, at $5 \%$ probability, in order to compare averages, using the statistical program SISVAR 3.01 (Ferreira, 2011).

\section{Results}

3.1. Total chlorophyll, stomatal conductance, water use efficiency and electrolyte leakage of cauliflower

In the absence of $\mathrm{Si}$, the authors noticed a decrease of total chlorophyll content with the addition of $\mathrm{NH}_{4}{ }^{+}$to the nutrient solution and in the presence of $\mathrm{Si}$, the total chlorophyll content was higher in N-A ratio of 50/50 (Fig. 2A). In the absence of Si, stomatal conductance increased when $\mathrm{NH}_{4}{ }^{+}$was applied, both in N-A ratios of 50/50 and 0/100. In the presence of $\mathrm{Si}$, the stomatal conductance was higher only in N-A ratio of 0/100 (Fig. 2B). Water use efficiency decreased with the application of $\mathrm{NH}_{4}{ }^{+}$, in the absence of $\mathrm{Si}$, and in the presence of $\mathrm{Si}$, there was an increase in water use efficiency in N-A ratio of 50/50 (Fig. 2C). Although the electrolyte leakage index had increased with the application of $\mathrm{NH}_{4}{ }^{+}$, the values were lower for plants nourished with Si (Fig. 2D). 


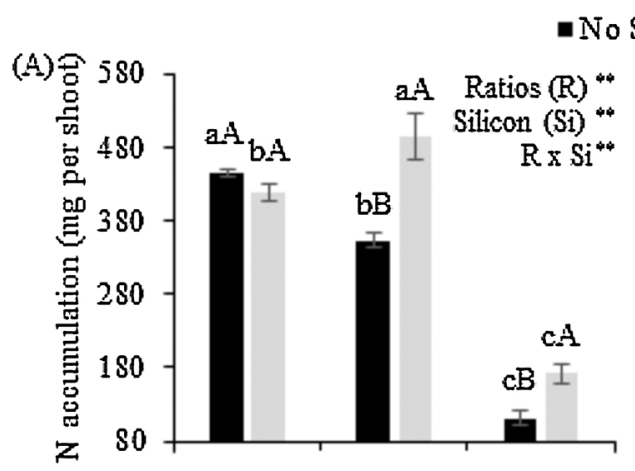

- No Si $=$ With Si

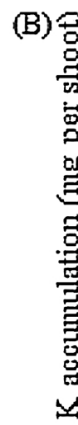

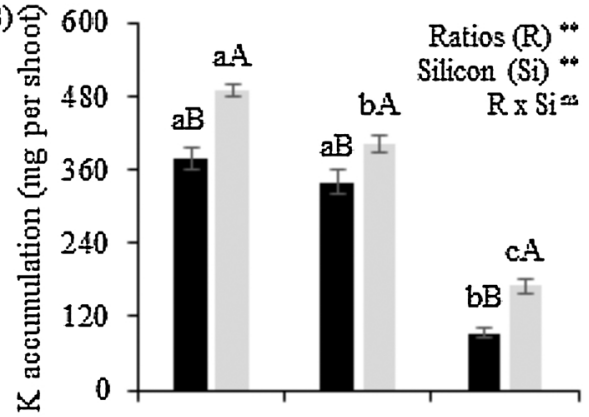

(C)

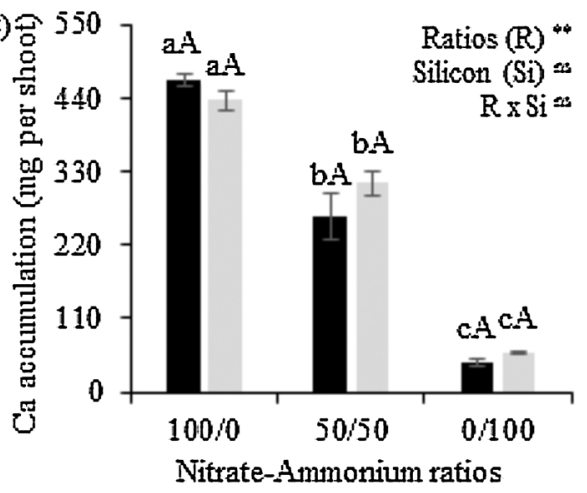

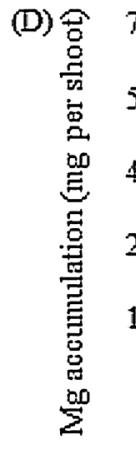

Fig. 3. Effect of $\mathrm{Si}$ and N-A ratios on (A) N, (B) K, (C) $\mathrm{Ca}$, (D) $\mathrm{Mg}$ and (E) Si accumulation of cauliflower shoot. The error bars in the figures represent standard error. Different letters, lowercase between N-A ratios in same $\mathrm{Si}$ concentration, and uppercase between $\mathrm{Si}$ in same $\mathrm{N}$-A ratio indicate differences (P $<0.05$, Tukey test) between treatments.

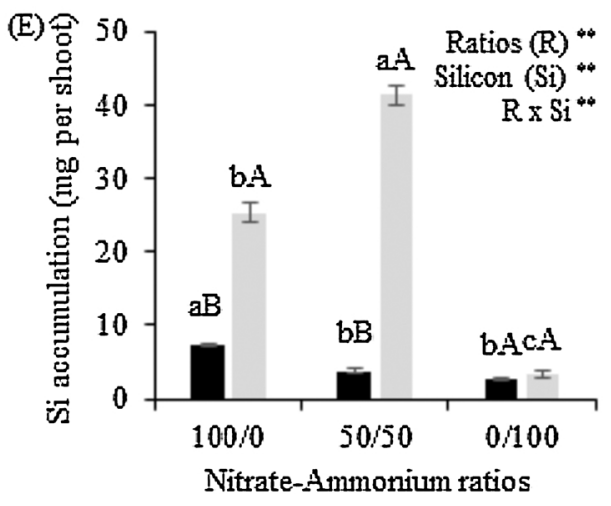

\subsection{The accumulation of $\mathrm{N}, \mathrm{K}, \mathrm{Ca}, \mathrm{Mg}$ and $\mathrm{Si}$ of cauliflower shoot}

In the absence of $\mathrm{Si}, \mathrm{N}$ accumulation decreased according to the application of $\mathrm{NH}_{4}{ }^{+}$. In the presence of $\mathrm{Si}, \mathrm{N}$ accumulation was higher in $\mathrm{N}-\mathrm{A}$ ratio of 50/50 (Fig. 3A), with similar effect for $\mathrm{Mg}$ accumulation (Fig. 3D). Although $\mathrm{K}$ accumulation had decreased with the application of $\mathrm{NH}_{4}^{+}$, the accumulation was higher in the presence of Si (Fig. 3B). For $\mathrm{Ca}$ accumulation, there was a decrease according to $\mathrm{NH}_{4}{ }^{+}$supply, regardless of $\mathrm{Si}$ application (Fig. 3C). In the presence of $\mathrm{Si}$, Si accumulation was higher in N-A ratio of 50/50, and lower in ratio of 0/100. In this same ratio, the authors did not notice any difference for $\mathrm{Si}$ accumulation in the absence of the element (Fig. 3E).

\subsection{Total chlorophyll, stomatal conductance, water use efficiency and} electrolyte leakage of broccoli

Total chlorophyll content was higher in N-A ratios of 100/0 and of
$50 / 50$. In ratio of 50/50, in the presence of $\mathrm{Si}$, there was the highest total chlorophyll content (Fig. 4A). Stomatal conductance increased with $\mathrm{N}$ supplied in the form of $\mathrm{NH}_{4}{ }^{+}$. However, $\mathrm{Si}$ decreased the stomatal conductance (Fig. 4B) and increased the water use efficiency in $\mathrm{N}$-A ratios of 100/0 and of 50/50 (Fig. 4C). Electrolyte leakage index increased with $\mathrm{NH}_{4}{ }^{+}$application, both in the absence and presence of Si (Fig. 4D).

\subsection{The accumulation of $\mathrm{N}, \mathrm{K}, \mathrm{Ca}, \mathrm{Mg}$ and $\mathrm{Si}$ of broccoli}

Regardless of Si supply, $\mathrm{N}$ accumulation in shoot of broccoli decreased when $\mathrm{N}$ was totally supplied in the form of ammoniacal (Fig. 5A). Nitrogen supplied in the form of $\mathrm{NO}_{3}{ }^{-}$provided higher $\mathrm{K}$ accumulation, in the presence of $\mathrm{Si}, \mathrm{K}$ accumulation was higher in all $\mathrm{N}$ A ratios (Fig. 5B), as well as accumulation of Ca (Fig. 5C) and $\mathrm{Mg}$ (Fig. 5D). Si supply provided higher accumulation of this element in NA ratio of 50/50, and in the absence of Si supply, no difference for 

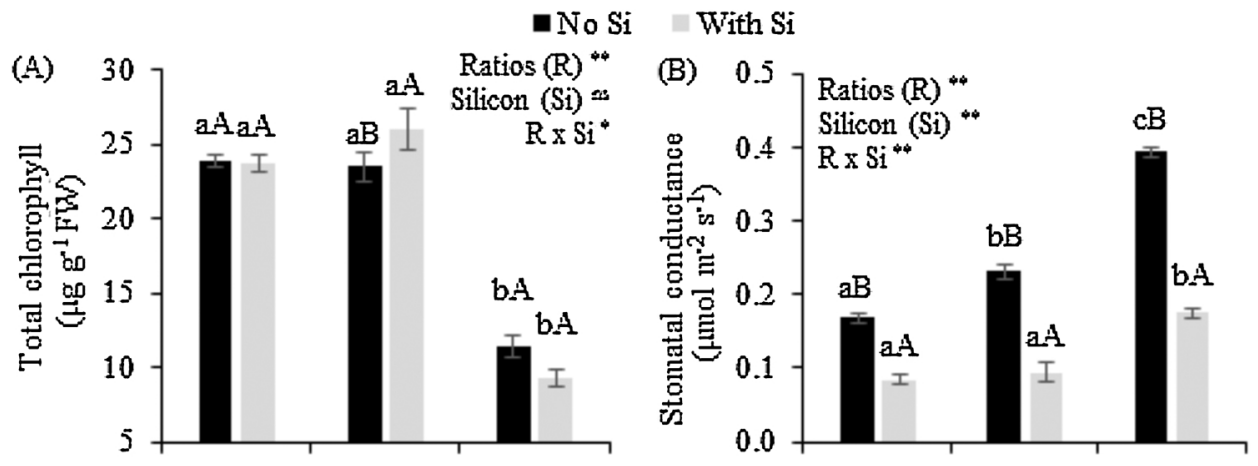

Fig. 4. Effect of $\mathrm{Si}$ and N-A ratios on (A) total chlorophyll, (B) stomatal conductance, (C) water use efficiency and (D) electrolyte leakage index of broccoli shoot. The error bars in the figures represent standard error. Different letters, lowercase between $\mathrm{N}-\mathrm{A}$ ratios in same $\mathrm{Si}$ concentration, and uppercase between $\mathrm{Si}$ in same N-A ratio indicate differences $(\mathrm{P}<0.05$, Tukey test) between treatments.

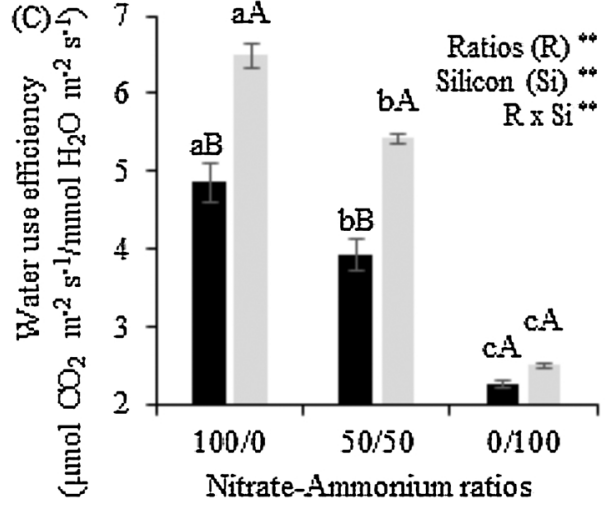

accumulation in N-A ratio was noticed (Fig. 5E).

\subsection{Plant growth}

For cauliflower, the increase of the amount of $\mathrm{NH}_{4}{ }^{+}$in the ratios decreased the leaf area, dry weight of shoots and roots. Nevertheless, $\mathrm{Si}$ increased leaf area, regardless of N-A ratio (Fig. 6A). In addition, $\mathrm{Si}$ provided an increase in dry weight production of shoots and roots in ratio 50/50 (Fig. 6B and C). For broccoli, in no Si, the increase of the amount of $\mathrm{NH}_{4}{ }^{+}$in the ratios decreased the leaf area. With $\mathrm{Si}$, the leaf area decreased only with $100 \% \mathrm{NH}_{4}{ }^{+}$(Fig. 6D). Dry weight of broccoli, both in roots and shoots decreased when $\mathrm{N}$ was totally supplied in the form of $\mathrm{NH}_{4}{ }^{+}$. However, in the presence of $\mathrm{Si}$, higher production of dry weight of shoots was noticed (Fig. 6E); on the other hand, no effect of the beneficial element for dry weight of roots could be observed (Fig. 6F).

\subsection{Images of shoots}

After the application of N-A ratios, starting at 37 DAS (25-Aug), the growth of cauliflower fed with $100 \% \mathrm{NH}_{4}{ }^{+}$was lower, in relation to the other treatments, until at 59 DAS (17-Sep), cauliflower plants fed $100 \%$ $\mathrm{NH}_{4}{ }^{+}$showed severe symptoms of $\mathrm{NH}_{4}{ }^{+}$toxicity, such as necrosis of new leaves and chlorotic dots on old leaves, regardless of the presence or absence of Si. On the same day (17-Sep), broccoli plants fed $100 \%$ $\mathrm{NH}_{4}{ }^{+}$were smaller than the other treatments. However, we did not observe the chlorosis or necrosis of the leaves (Fig. 7).

\subsection{Images of roots}

The roots of cauliflower and broccoli presented a clear coloration with $100 \% \mathrm{NO}_{3}{ }^{-}$. However, as the amount of $\mathrm{NH}_{4}{ }^{+}$increased, a progressive darkening of the roots of the two crops was noticed, highlighting the $\mathrm{NH}_{4}{ }^{+}$toxicity symptoms, regardless the presence or absence of Si (Fig. 8).

\section{Discussion}

In cauliflower and in broccoli, the highest total chlorophyll content (Figs. $2 \mathrm{~A}$ and $4 \mathrm{~A}$ ) is related to the highest $\mathrm{N}$ accumulation (Figs. $3 \mathrm{~A}$ and $5 \mathrm{~A}$ ) since $\mathrm{N}$ is present in the leaf chloroplasts, a constituent of the chlorophyll molecule (Hoertensteiner 2006). These results are due to the presence of $\mathrm{Si}$, in N-A ratio of 50/50, cauliflower and broccoli showed the highest $\mathrm{Si}$ accumulation in the shoots (Figs. $3 \mathrm{E}$ and $5 \mathrm{E}$ ), indicating that plants have no restriction on the absorption of this beneficial element. Moreover, the most evident role of Si under stress conditions (Epstein 2009) was confirmed in the same ratio, by decreasing the leaf area and shoot dry weight of cauliflower in $6.5 \%$ and $23 \%$, respectively (Fig. 6A and B). In broccoli, decreases in leaf area and shoot dry weight was 16.5 and $11 \%$, respectively (Fig. 6D and E) in the absence of Si. In this context, Si increased leaf area and fresh weight of Brassica napus with $14 \mathrm{mmol} \mathrm{L}^{-1} \mathrm{~N}$, in N-A ratios ranging from 100/0 to $25 / 75$ (Bybordi 2010).

Stomatal conductance did not show the same behavior for cauliflower (Fig. 2B) and broccoli (Fig. 4B). Possibly, lower stomatal conductance in plants nourished with Si had increased water use efficiency, being associated to formation of endodermal suberin lamellae (Vatehová et al., 2012). Thus, the highest water use efficiency in broccoli (Fig. 4C) was due to lower transpiration or higher photosynthetic rates when the plants were nourished with $\mathrm{Si}$, and when $\mathrm{NH}_{4}{ }^{+}$was the only $\mathrm{N}$ source, Zaghdoud et al. (2016a) also observed lower water use efficiency in broccoli plants fed with $3.5 \mathrm{mmol} \mathrm{L}^{-1}$ of $\mathrm{N}$ and $\mathrm{N}$-A ratios of $100 / 0,50 / 50$ and $0 / 100$.

Under the condition of $\mathrm{NH}_{4}^{+}$excess its conversion rate into amino 


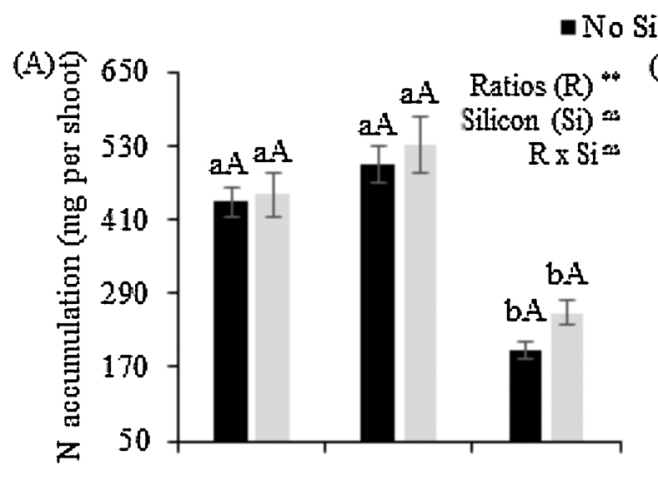

- No Si With Si

(B) 8

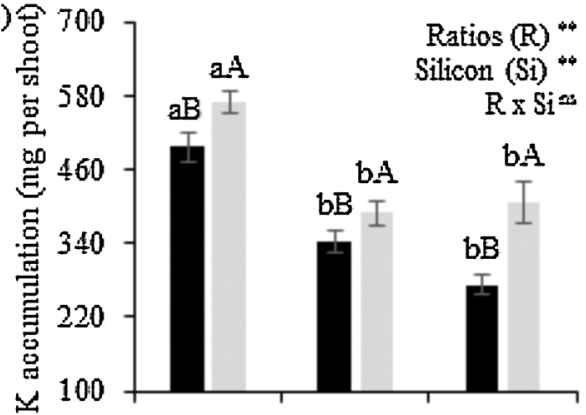

Fig. 5. Effect of $\mathrm{Si}$ and N-A ratios on (A) N, (B) K, (C) $\mathrm{Ca}$, (D) $\mathrm{Mg}$ and (E) Si accumulation of broccoli shoot. The error bars in the figures represent standard error. Different letters, lowercase between N-A ratios in same $\mathrm{Si}$ concentration, and uppercase between $\mathrm{Si}$ in same N-A ratio indicate differences $(\mathrm{P}<0.05$, Tukey test) between treatments.
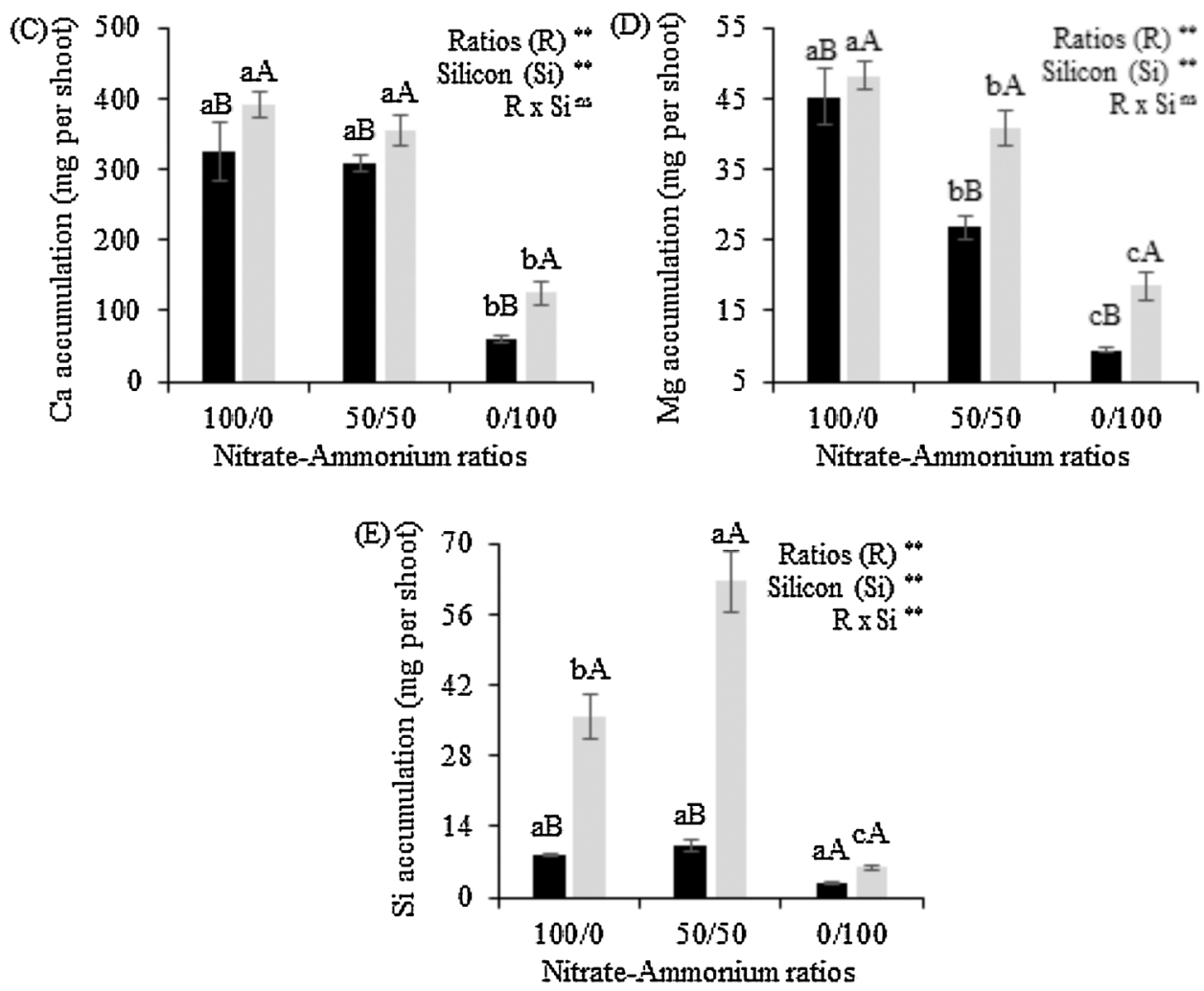

acid is lower than the absorption rate of this nutrient, leading to a $\mathrm{NH}_{4}{ }^{+}$accumulation in plant cell, which results in oxidative stress, due to the increase in the production of reactive oxygen species. Toxicity occurs when this production exceeded the cellular antioxidant capacity (Pandhair and Sekhon 2006), highlighted by the increase of electrolyte leakage index and the increase of $\mathrm{NH}_{4}{ }^{+}$ratio in cauliflower (Fig. 2D) and in broccoli (Fig. 4D). This fact occurs since this index is strongly correlated with the production of hydrogen peroxide, which is a byproduct of lipid peroxidation in stressed plants (Liu et al., 2013), inducing the visual symptoms in plants (Fig. 7).

Nevertheless, $\mathrm{Si}$ as an effective substance for alleviation of $\mathrm{NH}_{4}{ }^{+}$ toxicity is related to the increase of the activity of antioxidant enzymes, which act eliminating reactive oxygen species (Gao et al., 2014). Thus, $\mathrm{Si}$ supply was responsible for the lowest electrolyte leakage index in cauliflower plants (Fig. 2D), which was not observed for broccoli plants (Fig. 4D). So, in relation to physiological parameters, the results suggest that the alleviation of $\mathrm{NH}_{4}{ }^{+}$toxicity does not have the same behavior for both crops, since in cauliflower alleviation of $\mathrm{NH}_{4}{ }^{+}$toxicity in ratio of 50/50 (Fig. 6A) is related to the lowest electrolyte leakage index (Fig. 2D) and in broccoli, the alleviation of $\mathrm{NH}_{4}{ }^{+}$toxicity in all ratios, using Si (Fig. 6E) can be related to a higher water use efficiency (Fig. 4C).

In cauliflower and in broccoli, the lowest accumulation of $\mathrm{K}$ (Figs. 3 $\mathrm{B}$ and $5 \mathrm{~B}$ ) occurred due to the antagonistic effect of $\mathrm{NH}_{4}{ }^{+}$on this cation, since they are ions which compete for the same absorption sites (Marschner, 2012). In addition, the lowest accumulation of Ca (Figs. 3 $\mathrm{C}$ and $5 \mathrm{C}$ ) and $\mathrm{Mg}$ (Fig. 3D and 5D) was also observed by Ahmad et al. (2006) in cauliflower plants fed with $3.5 \mathrm{mmol} \mathrm{L}^{-1}$ of $\mathrm{N}$ and N-A ratios of $100 / 0,50 / 50$ and $0 / 100$. However, in the presence of $\mathrm{Si}$, both crops show higher accumulation of $\mathrm{K}$, and one possible explanation might be that $\mathrm{Si}$ stimulates membrane $\mathrm{H}^{+}$-ATPase activity, enzyme which is directly related to the $\mathrm{K}$ absorption (Liang, 1999). The mechanisms through which Si stimulates the absorption of other cations are still poorly studied. When $\mathrm{N}$ was totally supplied in the form of $\mathrm{NH}_{4}{ }^{+}$, the damage caused to the root system possibly affected the absorption of nutrients (Li et al., 2014). 

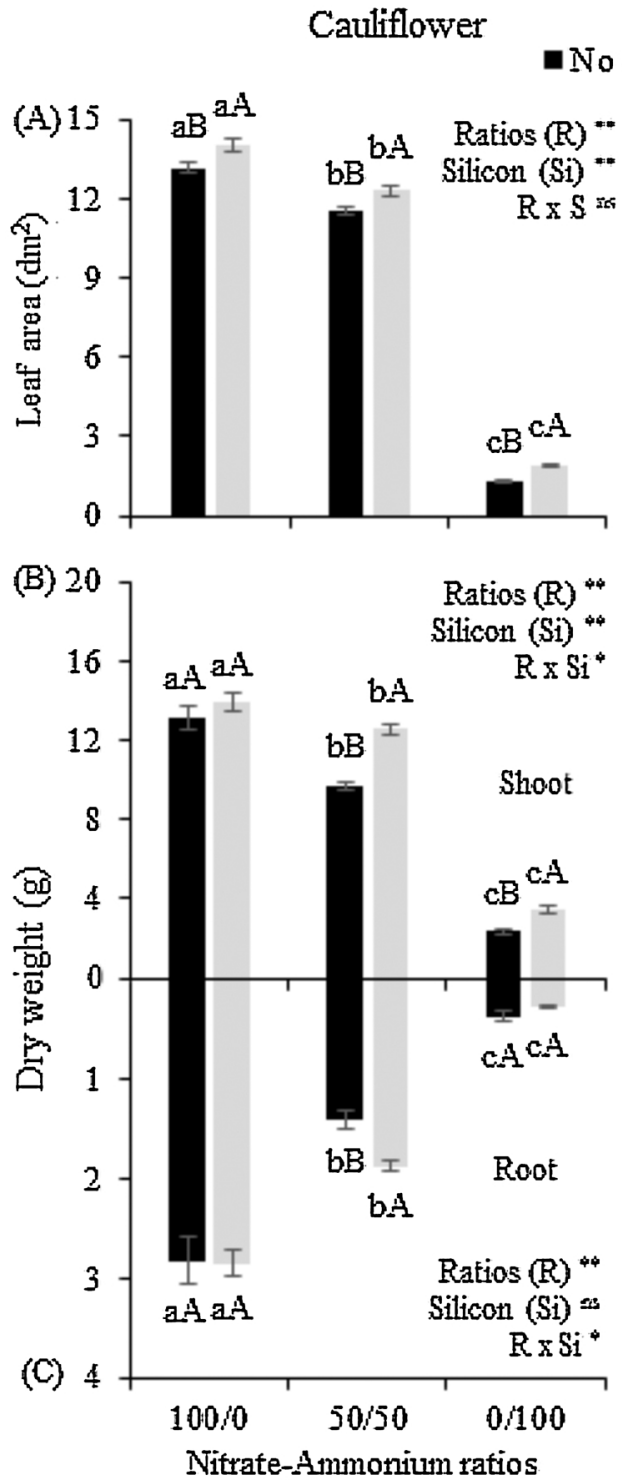

Broccoli

(D) 15

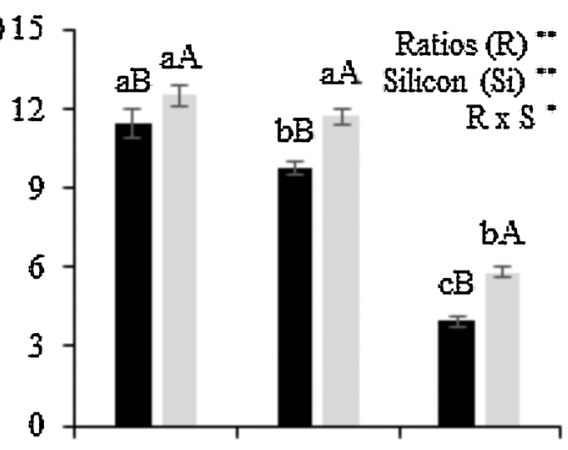

(E) 20

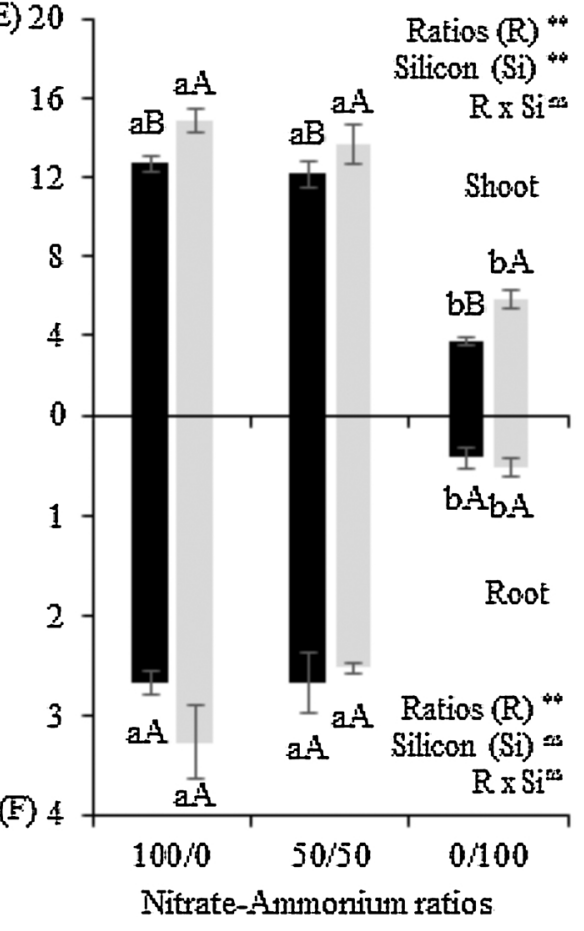

$A$

$B$
Fig. 6. Effect of $\mathrm{Si}$ and N-A ratios on (A) leaf area, (B) shoot dry weight and (C) root dry weight of cauliflower plant; (D) leaf area, (E) shoot dry weight and (F) root dry weight of broccoli plant. The error bars in the figures represent standard error. Different letters, lowercase between $\mathrm{N}$-A ratios in same $\mathrm{Si}$ concentration, and uppercase between $\mathrm{Si}$ in same NA ratio indicate differences $(\mathrm{P}<0.05$, Tukey test) between treatments. 
No $\mathrm{Si}$
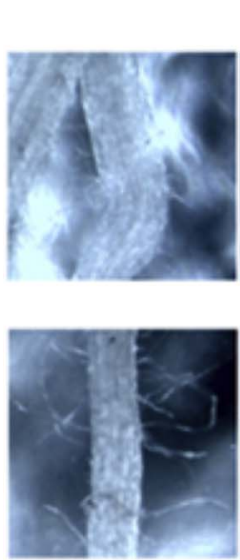

$100 / 0$

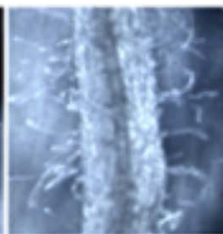

$50 / 50$
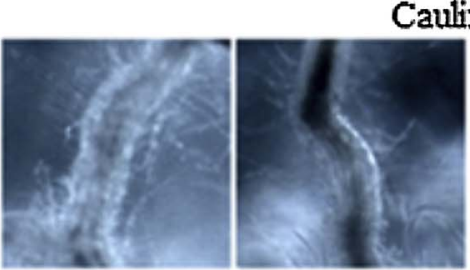

Cauliflower

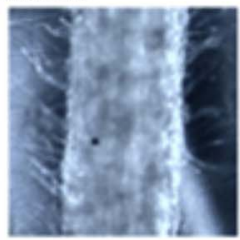

Broccoli

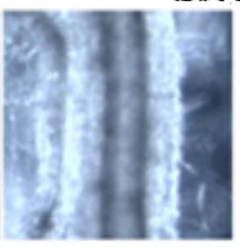

$0 / 100$

\section{Nitrate-Ammonium ratios}

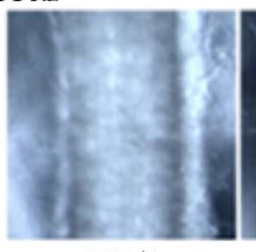

$100 / 0$
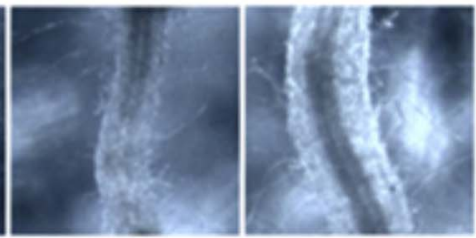

Wiht Si

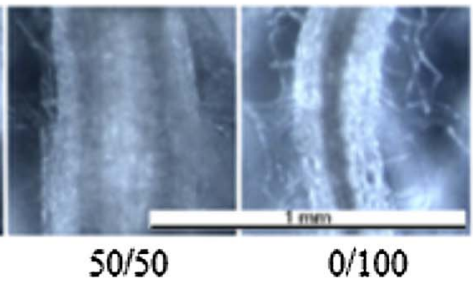

Nitrate-Ammonium ratios

Fig. 8. Effect of Si and N-A ratios on cauliflower and broccoli roots.

In relation to the dry weight production of cauliflower, no other studies were found in literature. Nevertheless, this parameter can be explained by $\mathrm{Si}$ benefits, in N-S ratio of 50/50, through the highest water use efficiency (Fig. 2C), the lowest electrolyte leakage index (Fig. 2D) and highest accumulation of $\mathrm{N}, \mathrm{K}, \mathrm{Ca}, \mathrm{Mg}$ and $\mathrm{Si}$ (Fig. 3), providing alleviation of ammoniacal toxicity (Fig. 6B).

Other studies on broccoli crop indicate that half of total $\mathrm{N}$ concentration in the nutrient solution can be in the ammoniacal form, without damaging the dry weight production or the plants (Zaghdoud et al., 2016a; Zaghdoud et al., 2016b), which was confirmed in this study, since the dry weight in N-A ratios of 100/0 and of 50/50 did not show any difference (Fig. 6E). However, Si acting positively in water use efficiency (Fig. 4C), and in accumulation of K (Fig. 5B), Ca (Fig. 5C) and $\mathrm{Mg}$ (Fig. 5D) increased the dry weight of the plants.

Thus, the results show that $\mathrm{Si}$ alleviates $\mathrm{NH}_{4}{ }^{+}$toxicity in cauliflower when the total $\mathrm{N}$ concentration is $15 \mathrm{mmol} \mathrm{L}^{-1}$ and $50 \%$ is supplied in the form of $\mathrm{NH}_{4}{ }^{+}$. In broccoli, $\mathrm{Si}$ improves the effect of $\mathrm{NO}_{3}{ }^{-}$and alleviates $\mathrm{NH}_{4}{ }^{+}$toxicity.

\section{References}

Ahmad, A., Mohd, S., Ismail, M.R., Yusop, M.K., Mahmood, M., 2006. Effects of nitrogen forms on the growth and ionic content of lowland cauliflower under tropical greenhouse. Acta Hortic. 710, 383-390. http://dx.doi.org/10.17660/ActaHortic.2006. 710.46 .

Bataglia, O.C., Furlani, A.M.C., Teixeira, J.P.F., Furlani, P.R., Gallo, J.R., 1983. Métodos de análise química de plantas. Instituto Agronômico de Campinas, Campinas 48p. (Boletim Técnico, 78).

Bittsánszky, A., Pilinszk, K., Gyulai, G., Komives, T., 2015. Overcoming ammonium toxicity. Plant Sci. 231, 184-190.

Bybordi, A., 2010. Influence of $\mathrm{NO}_{3}{ }^{-}: \mathrm{NH}_{4}{ }^{+}$ratios and silicon on growth, nitrate reductase activity and fatty acid composition of canola under saline conditions. Afr. J. Agric. Res. 5, 1984-1992. http://dx.doi.org/10.5897/AJAR09.064.

Dionisio-Sese, M.L., Tobita, S., 1998. Antioxidant responses of rice seedlings to salinity stress. Plant Sci. 135, 1-9.

Epstein, E., 2009. Silicon: its manifold roles in plants. Ann. Appl. Biol. 155, 155-160.

Ferreira, D.F., 2011. Sisvar: a computer statistical analysis system. Cienc. Agrotecnol. 35, 1039-1042.
Gao, Q., Wang, Y., Lu, X., 2014. Effects of exogenous silicon on physiological characteristics of cucumber seedlings under ammonium stress. J. Appl. Ecol. 25, 1395-1400.

Grevsen, K., 1998. Effects of temperature on head growth of broccoli (Brassica oleracea L. var. Italica): parameter estimates for a predictive model. J. Hortic. Sci. Biotechnol. 73, 235-244.

Hoagland, D.R., Arnon, D.I., 1950. The Water Culture Method for Growing Plants Without Soil. California Agricultural Experiment Station, Berkeley, CA.

Hoertensteiner, S., 2006. Chlorophyll degradation during senescence. Annu. Rev. Plant Biol. 57, 55-77.

Korndorfer, G.H., Pereira, H.S., Nolla, A., 2004. Análise de silício no solo, planta e fertilizante. UFU, Uberlândia 50 p. (Boletim técnico, v.2).

Li, B., Li, G., Kronzucker, H.J., Baluska, F., Shi, W., 2014. Ammonium stress in Arabidopsis: signaling, genetic loci, and physiological targets. Trends Plant Sci. 19, 107-114.

Liang, Y., 1999. Effects of silicon on enzyme activity and sodium, potassium and calcium concentration in barley under salt stress. Plant Soil 209, 217-224.

Lichtenthaler, H.K., 1987. Pigments of photosynthetic biomembranes. Method Enzymol. 148, 350-382.

Liu, L., Shelp, B.L., 1993. Nitrogen partitioning in greenhouse-grown broccoli in response to varying $\mathrm{NH}_{4}{ }^{+}: \mathrm{NO}_{3}{ }^{-}$ratios. Commun. Soil Sci. Plant Anal. 24, 45-60.

Liu, J., Zhang, H., Zhang, Y., Chai, T., 2013. Silicon attenuates cadmium toxicity in Solanum nigrum L. by reducing cadmium uptake and oxidative stress. Plant Physiol. Biochem. 68, 1-7.

Marschner, H., 2012. Mineral Nutrition of Higher Plants, 3. ed. Elsevier, Oxford 643 p.

Nasraoui-Hajaji, A., Gouia, H., 2014. Photosynthesis sensitivity to $\mathrm{NH}_{4}{ }^{-}-\mathrm{N}$ change with nitrogen fertilizer type. Plant Soil Environ. 60, 274-279.

Pandhair, V., Sekhon, B.S., 2006. Reactive oxygen species and antioxidants in plants: an overview. J. Plant Biochem. Biotechnol. 15, 71-78.

Ten Hoopen, F., Cuin, T.A., Pedas, P., Hegelund, J.N., Shabala, S., Schjoerring, J.K., Jahn, T.P., 2010. Competition between uptake of ammonium and potassium in barley and Arabidopsis roots: molecular mechanisms and physiological consequences. J. Exp. Bot. 61, 2303-2315. http://dx.doi.org/10.1093/jxb/erq057.

Vatehová, Z., Kollárová, K., Zelko, I., Richterová-Kučerová, D., Bujdoš, M., Lišková, D., 2012. Interaction of silicon and cadmium in Brassica juncea and Brassica napus. Biologia 67, 498-504 2012

Zaghdoud, C., Carvajal, M., Ferchichi, A., Martínez-Ballesta, M.C., 2016a. Water balance and N-metabolism in broccoli (Brassica oleracea L. var. Italica) plants depending on nitrogen source under salt stress and elevated $\mathrm{CO}_{2}$. Sci. Total Environ. 571, 763-771.

Zaghdoud, C., Carvajal, M., Moreno, D.A., Ferchichi, A., Martínez-Ballesta, M.C., 2016b. Health-promoting compounds of broccoli (Brassica oleracea L. var. Italica) plants as affected by nitrogen fertilisation in projected future climatic change environments. J. Sci. Food Agric. 96, 392-403. 